\title{
Das imagens da arte à criação em dança: afeto e ruído em Vincent
}

Images and creation in dance: affection, noise and fiction in Vincent

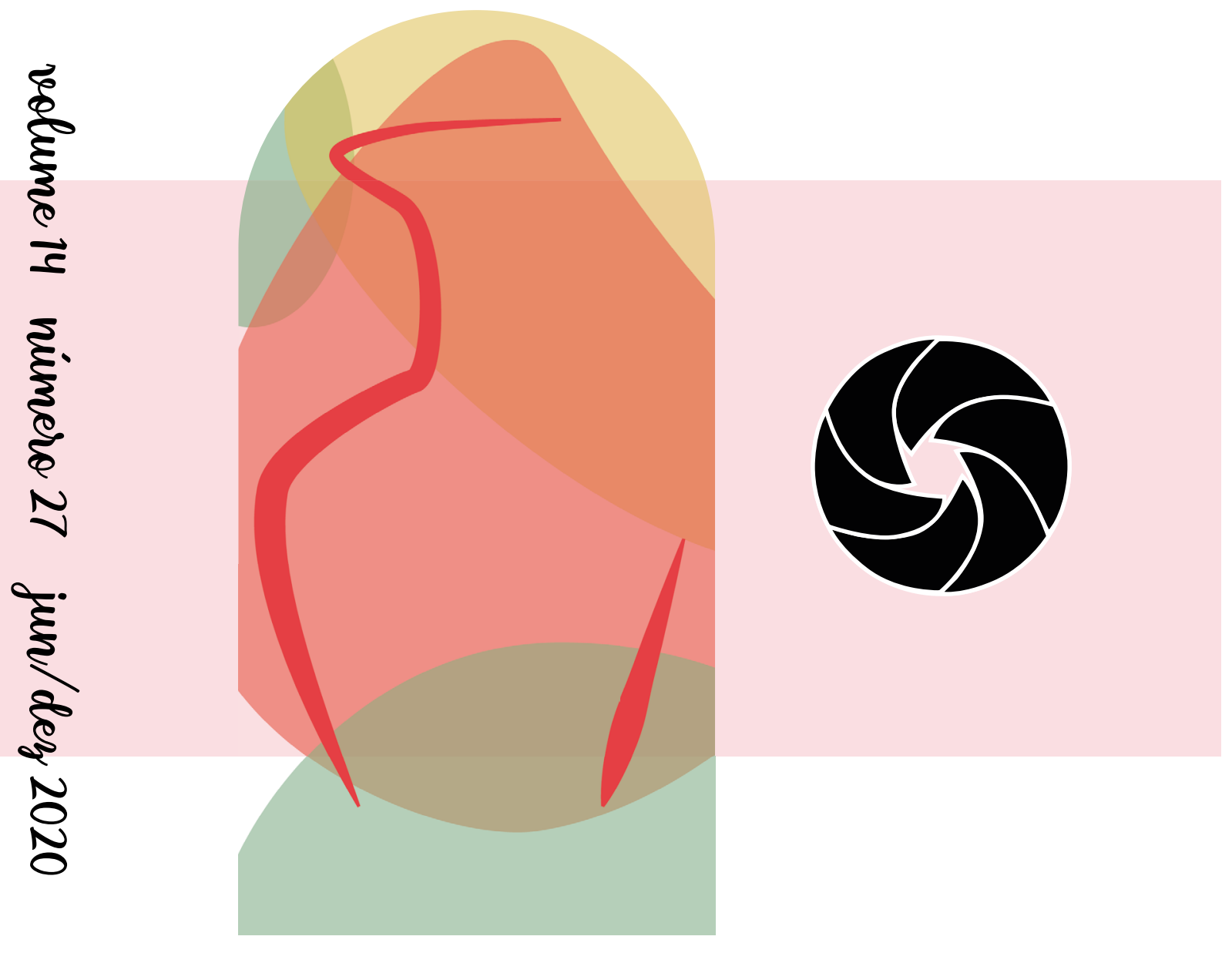

Daniel Silva Alire' daniel_airess@hotmail.com
Verônica Maria Prokopp de Oliveira ${ }^{2}$ vprokopp@gmail.com

Cultura Material: objetos, imagens e representacões - 1/2 


\section{Resumo}

Neste escrito busca-se refletir sobre o uso de imagens da obra do pintor holandês Vincent Van Gogh na criação do espetáculo Vincent, da Cubol Cia. de Arte estreado no ano de 2016 na cidade de Porto Alegre-RS. Compreende-se aqui o conjunto de obras-imagens-artefatos visitadas na composição do espetáculo de Dança Performativa, analisando-os a partir dos campos da Dança, da Cultura Visual e da Comunicação, na perspectiva de pesquisas baseadas na prática. Neste estudo apontam-se escolhas, estratégias, desdobramentos e suscitações imagéticas para elaborar afetos, ruídos e ficções como mote para a criação em Dança Performativa. Esboça-se por fim, a noção de imagem ruído como abordagem pertinente a criação em dança na contemporaneidade.

Palavras-chave: Ruído; Imagem; Criação em Dança; Van Gogh.

\section{Abstract}

This writing seeks to reflect on the use of images from the work of the Dutch painter Vincent Van Gogh in the creation of the show Vincent, by Cubol Cia. De Arte premiered in 2016 in the city of Porto Alegre-RS. It is understood here the set of works-images-artifacts visited in the composition of the Performative Dance show, analyzing them from the fields of Dance, Visual Culture and Communication, from the perspective of practice-based research. In this study we point out choices, strategies, unfoldings and imaginary excitations to elaborate affections, noises and fictions as motto for the creation in Performative Dance. Finally, the notion of image noise as a pertinent approach to contemporary dance creation is outlined.

Key-words: Noise; Image; Dance Creation; Van Gogh.
${ }^{1}$ Mestre e doutorando em Artes Cênicas pelo Programa de Pós-graduação em Artes Cênicas da Universidade Federal do Rio Grande do SUI (PPGAC-UFRGS), Porto Alegre-RS. Artista-pesquisador de danças e visualidades. Email: daniel_airess@hotmail.com

2 Mestra em Artes Cênicas pelo Programa de Pós-gradvação em Artes Cênicas da Universidade Federal do Rio Grande do Sul (PPGAC-UFRGS), Porto Alegre-RS, doutoranda no Programa de Pós-gradvação em Ciências do Movimento Humano da Universidade Federal do Rio Grande do Sul (PPGCMH-UFRGS), Porto Alegre-RS. Artista-pesquisadora. Email: vprokopp@ gmail.com 
3 Vincent Van Gogh (1853-1890) é considerado o primeiro grande mestre da pintura holandesa desde o século XVI. $O$ pintor tem seu pertencimento estético posicionado no estilo pós-impressionista ao lado de Cézanne e Seurat (JANSON, 2001). Seu famigerado nome está carregado das marcas de suas pinceladas que nos levam a um "estado de fluxo", inerente à sua pintura.

\footnotetext{
${ }^{4}$ Referimo-nos a Esquizofrenia de Vincent.
}

\section{Um esboço da imagem- ideia}

Vincent Van Gogh é um dos pintores mais cultuados da atualidade. Nascido aos 30 dias de março de 1853 em Groot Zundert - Holanda, o pintor pós-impressionista ${ }^{3}$ é protagonista em uma história de vida conturbada, tingida pelas crises de sua doença ${ }^{4}$ e acentuada pelos matizes de sua extensa obra, que elabora tensão, drama e amor ao sacerdócio da arte. Da fluidez e ritmo encontrados em sua obra "O dinamismo que anima todas as pinceladas faz de cada uma delas não uma simples marca de cor, mas um incisivo gesto gráfico" (JANSON, 2001) que entrecruza o conturbado estado esquizofrênico que move grande parte de sua produção. As pinceladas marcantes e o estudo impecável da cor exposto nas cartas (VAN GOGH, 2016) que trocava com seu irmão Théo Van Gogh, engendram uma produção de mais de 860 pinturas à óleo dos gêneros retrato, autorretrato, paisagem, natureza morta e cômodos das moradias frequentadas pelo artista. A consciência paradoxal de seu estado psíquico alternando sobriedade, fé e as crises frequentes do final de sua vida, colaboram para um estado constante de interesse dos mais variados públicos, bem como de outros artistas, na construção de desdobramentos artísticos a partir de sua obra e do imaginário construído sobre Vincent. A Cubol Cia. de Arte, interessada no cruzamento entre Artes Visuais e Dança, aproxima-se desse interesse pela pintura e pela vida de Van Gogh na elaboração de seu espetáculo Vincent, ganhador do Prêmio Açorianos de Dança na categoria Coreografia no ano de 2017.

Esse modo de operar em dança a partir de imagens e, principalmente, a partir de imagens de pinturas e de artistas timbrados na história das artes é algo que se familiariza com a criação de outros coreógrafos que antecedem o trabalho coreográfico estudado aqui e que também se inscrevem nesta mesma história, tal como nos indica Bernard:

Assim, sabemos o fascínio exercido sobre Trisha Brown pelas produções plásticas de Robert Rauschenberg, Andy Warhol, Jasper Johns, Donald Judd ou, na escola francesa, a influência predominante das imagens barrocas e da fotografia em Karine Saporta, a obsessão da pintura vienense expressionista de Egon Schiele e Klimt por Christian Bourigault, o interesse exclusivo de Jean-Marc Matos pelas imagens projetadas e, mais particularmente, pelas imagens geradas por computador digital ou moldadas pelas novas tecnologias da computação. Poderíamos multiplicar os exemplos, mas deixe-nos aqui apontar esse fato incontestável: muitos coreógrafos afirmam ter raízes ou, se preferir, elaborar sua criação coreográfica à percepção de uma imagem. (BERNARD, 2001, p. 137, tradução nossa). 
Esta aparição de Van Gogh na pesquisa em Dança, não desmerece ou menospreza o uso de imagens do cotidiano em favor das obras de arte. Muito pelo contrário, nosso desejo em recorrer às obras de arte se dá na busca de compreensão dos contextos das imagens visitadas, atualizando e transformando nossas imagens corriqueiras em uma pesquisa de movimento. Pensar a construção de um espetáculo de dança a partir de um referencial tão expressivo da história da arte não demonstra uma proposição que busca ser inovadora, e de fato, não foi. A inquietação que rondou os quatro corpos dispostos ao pensar-fazer dança consistia em transitar entre a vida e a obra de Van Gogh de maneira não linear, não narrativa, para isso foi necessária uma inesgotável pesquisa no universo do artista. Inesgotável pois transita até hoje, em constante desdobramento. Em alguns momentos desta investigação, se misturam obras, contextos e artistas. Por esta razão o leitor encontrará no andamento do texto o nome Van Gogh se referindo ao artista de referência, Vincent se referindo ao espetáculo em si e intérpretes-criadores quanto aos bailarinos que dão corpo ao espetáculo da Cubol Cia. de Arte.

Pensando com Damásio (2011) e Berté (2015) podemos investigar esse processo criativo na perspectiva de cruzamentos entre a obra de Van Gogh, carregada de outras imagens e das histórias que a engendram, com aquilo da vida dos intérpretes-criadores. Em uma perspectiva genética do espetáculo de Dança, precisamos atentar ao fato de que essas imagens nos interessam não pelo suposto preciosismo de se tratar de um grande artista, mas naquilo de suas imagens que podemos transitar em desdobramentos, que só podem ocorrer quando às oferecemos, em sua potência performativa, à experiência nos corpos. Parafraseando Pesavento (2008), ao vislumbrarmos uma imagem, esta entra em relação com o "museu imaginário" ou ainda com o "arquivo de memória" (PESAVENTO, 2008, p. 101) particular de cada indivíduo. No entanto, "as imagens possuem poderes bem definidos: são sedutoras e evocativas, despertando a memória e conectando-a a outras experiências" (PESAVENTO, 2008, p. 106).

Esta experiência em Dança ocorre então na pesquisa e seleção das imagens de Van Gogh a procura daquilo que engendra estas obras, ou seja, os aspectos da vida do artista no momento de criação destas imagens. Para tal, tomamos emprestado do campo da fotografia um caminho nomeado por Boris Kossoy (2002) como as "Realidades da Fotografia":

A primeira realidade é o pró-
prio passado. A primeira rea-
lidade é a realidade do as-
sunto em si na dimensão da
vida passada, diz respeito a
história particular do assunto,
[...] ao contexto deste assun-
to no momento do ato do re-
gistro. A segunda realidade é
a realidade do assunto repre-
sentado, contido nos limites
bidimensionais da imagem
fotográfica não importando 
qual seja o suporte no qual esta imagem se encontre gravada [...]. (KOSSOY, 2002, p. 36-37, grifo do autor).

Dessa maneira, os motes de criação para o espetáculo Vincent desenvolvem-se a partir do contexto e do acontecimento que cerceia as obras de Van Gogh, ou seja, a primeira realidade da imagem. A apreciação formal das linhas, cores e aspectos compositivos das obras foram também elementos disparadores para esta criação em dança. Se compreendermos a experiência enquanto "combinação sutil e fluida de imagens de fenômenos em curso e de imagens evocadas, em proposição sempre mutáveis" (DAMASIO, 2011, p. 96), faz-se necessário compreender que este fluxo de mudanças dá-se na interação entre os corpos dos bailarinos interagindo entre si, com os ambientes e com as imagens propulsoras dessa criação.

Se o conjunto de imagens utilizado na construção de Vincent possui essa capacidade de articulação, percebe-se que os modos de cada intérprete operar a partir dos comandos da propositora (diretora) se tornam infinitos de possibilidades, assim como os desdobramentos que acontecem em cada corpo. A trama é tão complexa que os corpos munidos de suas experiências com - mover/dançar só podem dar a ver aquilo que se transforma a partir dos sensores neuronais, tramando e compondo os mapas cerebrais que Damasio (2011) compreende serem a base das imagens mentais. Sobre isso, Berté (2018) defende que:
As imagens mentais ganham mais ou menos destaque no fluxo vital conforme o valor que têm para o indivíduo, valor esse que provém do conjunto de disposições que regula e orienta a vida e também dos valores que atribuímos a todas as imagens que adquirimos ao longo de nossa existência. A mente se ocupa tanto das imagens que entram quanto daquelas que já estão no corpomente, escolhidas e editadas, favorecidas pelo nosso sistema biológico-cultural. As imagens mentais são representações baseadas nas mudanças que ocorrem no corpo e no cérebro durante a interação física de corpo com objetos, outros corpos, situações, em suma, com o mundo. (BERTÉ, 2018, p. 189).

Cabe aqui garantir à compreensão do leitor de que o conjunto citado pelo autor como "as imagens que entram e as que já estão" não estão 'alocados' em lugares imunes de relações, ou seja, essas imagens que entram, selecionadas e editadas, assim o são feitas sempre em interação ao que já está. Não há entrada que se faça sem o cruzamento de um conjunto do todo, do qual somos feitos. É dessa não imunidade de cruzamentos que podemos devolver ao mundo, a todo o tempo, outras imagens já mediadas ou de alguma forma digeridas.

As interações entre imagens e procedimentos de criação em Dança se fazem presentes de distintas formas ao longo da história. Podemos citar dois exemplos de criadoras 
de forte influência em nosso tempo: a brasileira Lenora Lobo (1956-) e a alemã Pina Bausch (1940-2009). Lenora Lobo desenvolveu seu método de criação intitulado Teatro do Movimento e este se desenvolve a partir da triangulação dos vértices Corpo Cênico, Movimento Estruturado e Imaginário Criativo. Para Lobo e Navas (2007) o terceiro vértice engloba aspectos das experiências dos artistas, vividos e sentidos na produção e seleção de imagens, percebidas pelos cinco sentidos ao longo da vida. As autoras destacam a imaginação enquanto "faculdade de representar ou evocar imagens já percebidas, podendo também ser a faculdade de criar ou inventar" onde o imaginário do artista é composto destas imagens internas "imbuídas de sua afetividade e história de vida". (LOBO; NAVAS, 2007, p. 185). Outra definição apresentada pelas autoras e que nos ajuda na elaboração do foco deste escrito diz respeito diretamente ao que estamos compreendendo enquanto imagem:

Se a palavra imagem também pode ser compreendida enquanto a representação de um objeto, impressão ou lembrança, para os artistas, ela alcança outro sentido: é a manifestação do sensível, do abstrato, do invisível. Para a dança é a metáfora do corpo em movimento. (LOBO; NAVAS, 2007, p. 185).

As autoras destacam ainda os dois tipos de procedimentos utilizados por coreógrafos acerca do imaginário criativo: o primeiro, volta-se para o interior e para as subjetividades dos artistas; já o segundo, para escolhas externas e racionais. Concluem que nenhum dos dois casos lidam com a consciência ou com questionamentos sobre como a escolha desses conteúdos (imagens) se procede.

A célebre coreógrafa alemã Pina Bausch que realizava métodos de perguntas e respostas com seus bailarinos evocando seus afetos para compor dança a partir da diversidade de suas experiências, recrutava de seus bailarinos a "habitar o objeto-tema" de forma a "coletar material". Esse material se tratava de imagens criadas e evocadas pelos artistas a partir de seu tema, as quais a coreógrafa selecionava e editava "como um diretor de cinema" (CALDEIRA, 2010, p.124). Essas edições das imagens geradas pelo corpo elaboravam-se enquanto repetições, fragmentações e justaposições com as quais "escrevia uma peça com um vocabulário especialíssimo" (CALDEIRA, 2010, p.127) em um caminho apresentado por Caldeira (2010) como escrita de dança dramático-fímica.

A partir destas duas criadoras passaremos a abordagem do espetáculo Vincent, com a qual percorreremos pelos usos e tratamentos das imagens não apenas enquanto imaginário criativo, mas investigando as imagens ruído como aquilo das fendas da imagem da arte, pictórica, e seus desdobramentos na construção de outras imagens-mundo materializadoras desta criação em dança. Trataremos do ruído da imagem como recurso da não reificação da obra de arte, do ruído enquanto potência na arte contemporânea. 
A Cubol Cia. de Arte é um coletivo independente criado em 2014 pelos artistas Daniel Aires, Fellipe Resende, Richard Salles e Verônica Prokopp que trabalha com pesquisa em Dança, Performance e Artes Visuais atuando na cidade de Porto Alegre-RS. Já participou de eventos como o $25^{\circ}$ Porto Alegre em Cena (2018) e $10^{\circ}$ Caxias em Movimento (2019).

6 As informações especulativas, muitas delas discutidas entre pesquisadores especializados na biografia de Van Gogh, geram pontos controversos. A partir disso, destaca-se que o encontro entre Van Gogh e Hoornik aconteceu em 1882, muito antes de 25/12/1888, data da auto-mutilação. Esses hiatos e informações não factíveis, não verossímeis, não são descartadas aqui, ao contrário, ajudam a elaborar o que estamos propondo aqui enquanto ruídos da imagem, ao longo do texto.

\section{Imagens compositivas na elaboração de Vincent}

O espetáculo Vincent da Cubol Cia. de Arte 5 é composto por 08 (oito) cenas as quais abarcam 10 (dez) das principais obras do pintor holandês: Autorretrato com a Orelha Cortada (1889), Campo de Trigo com Corvos (1890), O par de Sapatos (1886), A cadeira com o Cachimbo (1888), A Noite Estrelada (1889), Os comedores de Batatas (1885), Pietá (1889), O Carteiro Roulin (1888), Os Girassóis (1888) e $O$ quarto em Arles (1888). Além disso, faz-se também uma referência as cartas que o pintor trocou ao longo de sua vida com o irmão Theo.

Figura 1. Self-Portrait with Bandaged Ear Vincent van Gogh, Arles, January 1889.

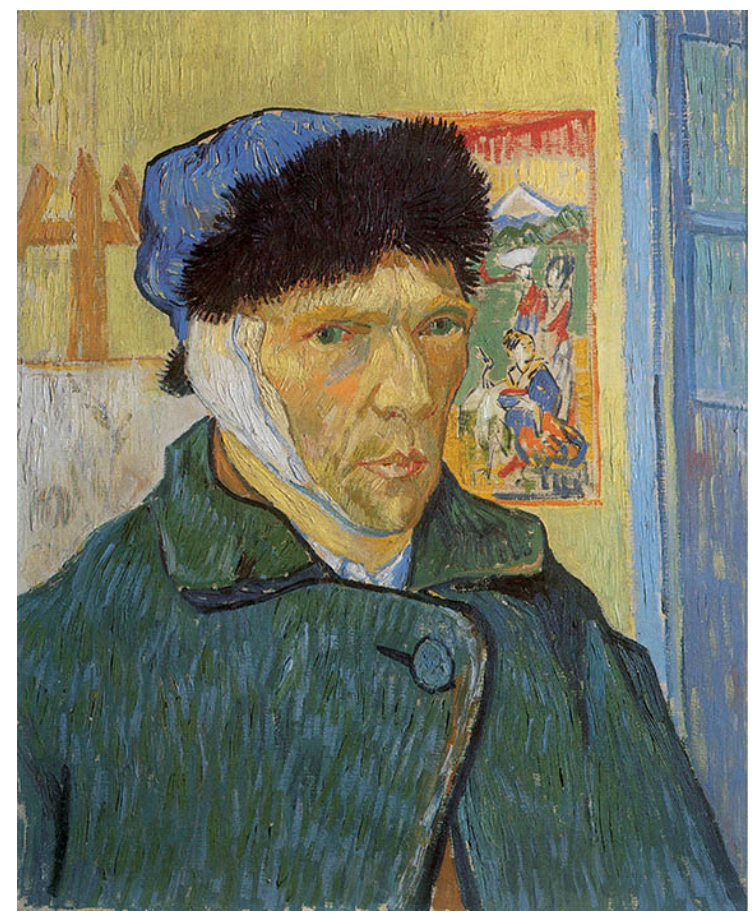

Fonte: The Samuel Courtauld Trust, The Courtauld Gallery, Londona.

A obra Autorretrato com a Orelha Cortada (Self-Portrait with Bandaged Ear, 1889, figura 1) inspira a primeira cena do espetáculo, a qual nomeamos como Eu te amo, ou ainda Cena do Brinco. Nesta imagem tem-se a figura do próprio pintor com uma bandagem envolvendo sua cabeça protegendo-lhe as orelhas, retrato da auto-mutilação que Vah Gogh teria cometido em razão da prova de seu amor por Sien Hoornik. Há, no entanto, especulações a respeito do motivo do corte da orelha: alguns historiadores como Naifeh; Smith (2012) apontam o desentendimento com seu amigo e sócio Paul Gauguin como uma possível causa da auto-mutilação, ao contrário de crendices ${ }^{6}$ que apontam o amor não correspondido de Hoornik e o fato desta mulher o ter abandonado. Tais especulações, histórias com maior ou menor grau de ficção, são vistas aqui como matéria criativa para a composição em Dança, como imagens-artefatos da cultura, como nos aponta Martins (2007), nos levando a manuseá-la com potência interpretativa.

Para Berté (2015) as imagens-artefatos estão em sua dança para além da representação, antes, estão a confrontarem-se com a rede complexa de vivências/ experiências dos corpos - seu "ver-sentir-pensar". Esta tríade verbal se insere também na observação de Tourinho e Martins (2013) quanto ao espaço em que essas imagens-artefato estão contextualizadas. São imagens-artefatos-mundos, uma vez que, transitam sempre deixando um pouco de si e carregando um pouco do outro (aquele com quem se relaciona, e, com o meio no qual se relaciona). 
Destas narrativas por trás da imagem surge logo um adereço utilizado no processo de criação: o brinco. Este elemento apresenta-se enquanto uma alegoria que carrega um duplo sentido: ao mesmo tempo que faz menção a Sien Hoornik e a paixão de Van Gogh, ele também representa a memória de uma pessoa amada por cada um dos intérpretes-criadores. No decorrer do processo de criação cada vez que os intérpretes se relacionavam com este objeto, eles estavam relacionando-se com sua própria memória amorosa/afetiva. Utilizamos um gesto de levar a mão até a orelha, encobrindo o brinco vestido em uma das orelhas, onde, a escolha deste brinco foi feita a partir de um questionário elaborado para que cada um dos intérpretes evocasse as características da pessoa considerada como seu grande amor.

Com essas características chegou-se à cor que lembraria a personalidade desta pessoa e a partir disso elaboramos duas diretrizes: A primeira consistia na caligrafia do nome da pessoa em questão, que deveria ser desenhada com alguma parte do corpo de modo que esse nome estivesse diluído na movimentação desenvolvida na cena. A segunda diretriz era 'digam Eu te amo', desdobrada em pronunciar alguma palavra ou pequena frase de sentido que remetesse os intérpretes a essa relação. De certo modo, essas duas diretrizes foram temperando a criação das movimentações sem perder o aspecto condutor/dramatúrgico da cena e mantendo a relação com a obra de Van Gogh anteriormente citada (figura 1) que se elaborava como: Contem para o público sobre essa pessoa, sobre seu amor.

Figura 2. Vincent (2017) - Cena do Brinco Sala Álvaro Moreyra, Porto Alegre-RS.
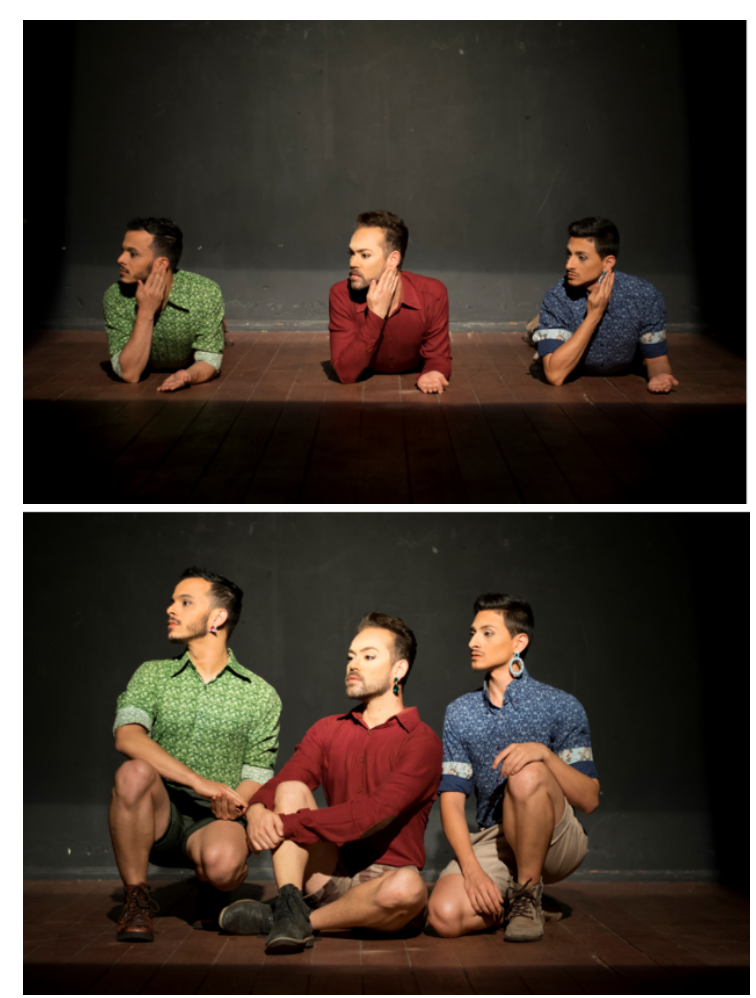

Fonte: Acervo da Cubol Cia. de Arte. Fotografia: Luhã Valença.

Além das diretrizes que se elaboraram a partir do Autorretrato com a Orelha Cortada (1889), parafraseado com gestos e movimentos explorados e construídos minuciosamente pelos intérpretes-criadores, outro aspecto que funda a elaboração desta primeira cena é o espaço onde ela se desenvolveu: a Sala $209^{7}$ da Usina do Gasômetro em Porto Alegre-RS. A grande sala aberta continha um pequeno palco ao fundo e costumava ser utilizado em apresentações menores por outros artistas que a utilizavam em toda sua extensão.
O acesso a este espaço se deu através do $7^{\circ}$ Programa de Residência Artística Sala 209, através do Projeto Usina das Artes, Eduardo Severino Companhia de Danca e Ânima Cia. de Dança com o apoio da Prefeitura Municipal de Porto Alegre RS o que nos permitiu desenvolver a pesquisa, criação e estreia da primeira temporada de Vincent em dezembro de 2016. 
Consideramos desde o início que a montagem se daria enquanto $v$ elaborado desde a pesquisa de movimento até sua apresentação em função da ocupação do espaço. Pensamos do início, além de ocupar a sala e o palco como espaço para a ação, em dispor a plateia em ilhas ao longo do espaço, no entanto se assim o tivéssemos feito, teríamos perdido a fluência que o espaço aberto possibilita.

9 Localizada junto ao Centro Municipal de Cultura, Arte e Lazer Lupicínio Rodrigues (Av. Érico Veríssimo, 307 na cidade de Porto Alegre - RS).
Nossa ideia era ocupar ${ }^{8}$ ospaço como um todo, sem isolar ou dar ênfase ao palco italiano em si e sim na possibilidade de utilizá-lo de forma que a cena escorresse por sua borda até tomar todo o espaço (figura 3). Pensando nisso, nossa pesquisa de movimento considerou este aspecto e finalizou esta etapa com a cena desdobrando-se como pretendido, ganhando o espaço.

Figura 3. Elaboração da primeira cena do espetáculo Vincent na Sala 209 (Primeira temporada) da Usina do Gasômetro, Porto Alegre-RS (2016).
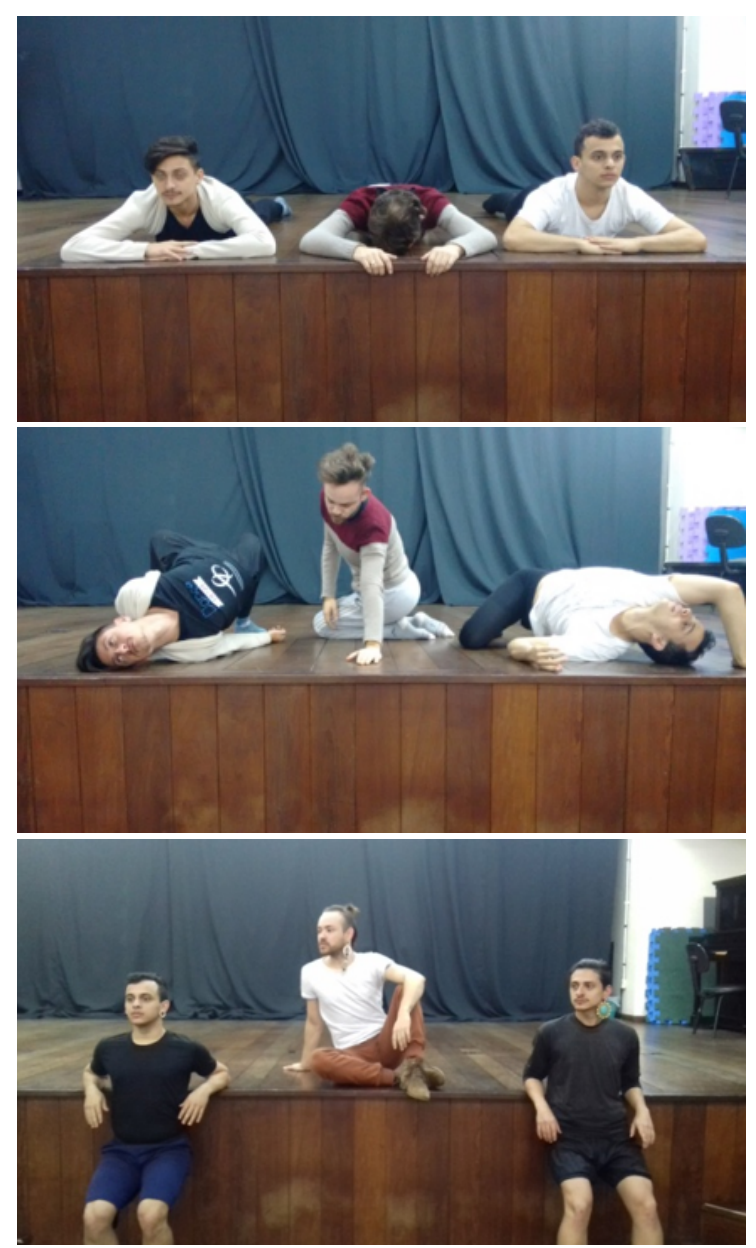

Fonte: Acervo da Cubol Cia de Arte. Registro de ensaio. Fotografia: Verônica Prokopp.

$\mathrm{Na}$ segunda temporada de Vincent, em 2017, apresentada na Sala Álvaro Moreyra?, esta mesma característica de ocupação do es- paço nos exigiu uma adaptação. Na Sala 209, iniciávamos a cena deitados no chão do palco o que possibilitava uma leitura equilibrada à linha de visão do espectador. Já na Sala Álvaro Moreyra, espaço sem palco e com a plateia no mesmo nível onde ocorre a ação, iniciar esta cena deitados desequilibrava não só a linha de visão do espectador como também não contribuía com a dramaturgia cênica a qual buscava dividir com o público sobre os amores de cada artista.

Para resolver esta questão cênica e dramatúrgica, acolhemos a sugestão da iluminadora de que a cena se mantivesse iniciando no chão, mas desta vez com um recorte de luz definindo o espaço restrito ao fundo da caixa cênica, colocando assim em evidência os pequenos gestos que conduziram toda a ação da primeira cena (figura 4).

Figura 4. Vincent (2017) - Segunda Temporada na Sala Álvaro Moreyra, Porto Alegre-RS.

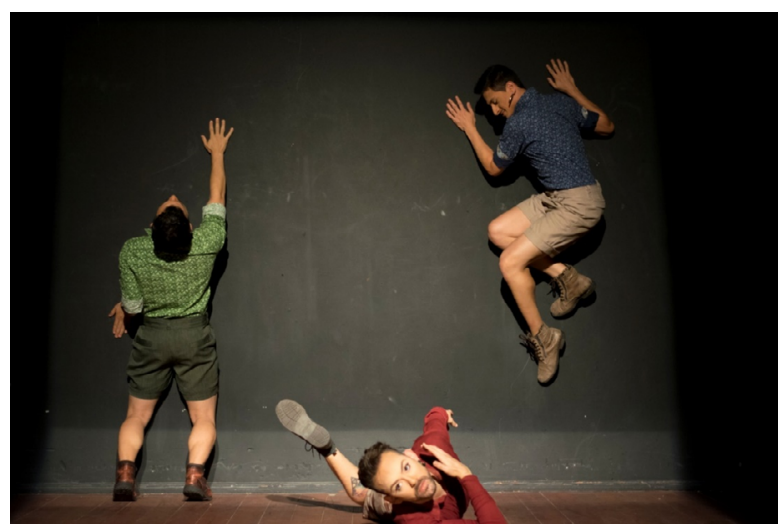

Fonte: Acervo da Cubol Cia. de Arte. Fotografia: Luhã Valença.

A segunda cena de Vincent traz um dos elementos mais icônicos da obra de Van Gogh, os Girassóis (figura 5). Na tentativa de construir 
um ateliê / espaço artístico o artista criou oito telas de Girassóis para esperar a chegada de Paul Gauguin, seu até então amigo e parceiro nesta empreitada. A pergunta chave que norteia a criação desta cena é: como ter girassóis sem ter girassóis?

Figura 5. Sunflowers - Vincent Van Gogh 1889.

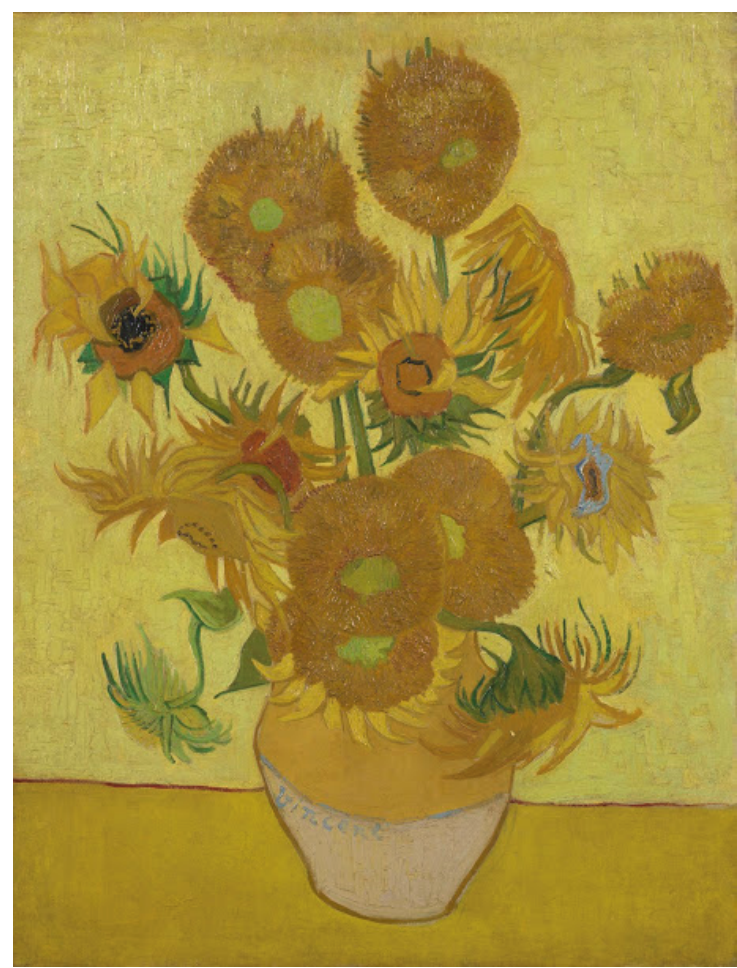

Fonte: https://www.vangoghmuseum.nl/ en/collection/s0031V1962.

A partir disso, servimo-nos do conceito de alegoria do campo das Artes Visuais e o que se apresenta na cena são então, sementes de girassóis. Abrigadas dentro de um balde de alumínio, o espectador só visualiza essas sementes no ato coreográfico, quando o intérprete-criador as lança para cima em um movimento frenético, explosivo e repetitivo (figura 6), além de deslocar-se pelo espaço derramando o conteúdo do balde afim de formar uma trilha como uma espécie de semeadura ao fundo do espaço cênico.
Figura 6. Vincent (2017) - Cena dos Girassóis

- Sala Álvaro Moreyra, Porto Alegre-RS.
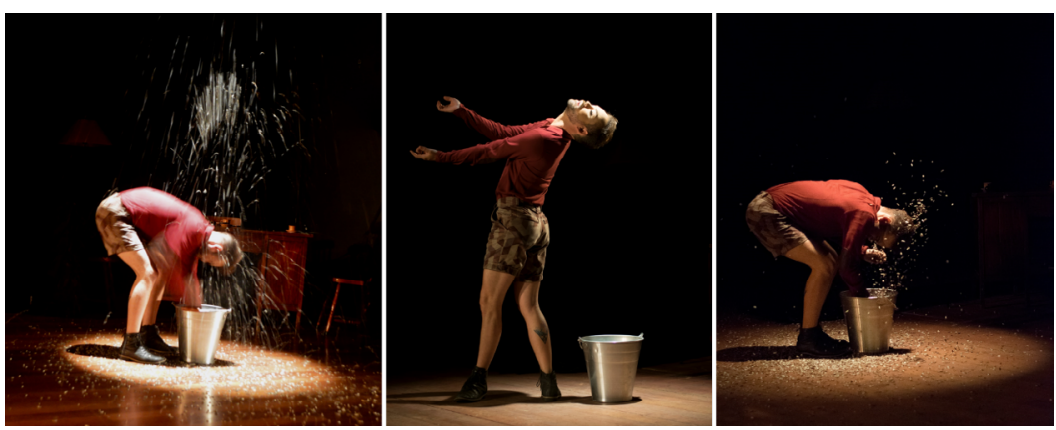

Fonte: Acervo da Cubol Cia. de Arte. Fotografia: Lu Trevisan e Luhã Valença.

Este rastro é a margem de criação e execução da cena número quatro do espetáculo, onde esta trilha será "apagada". Os girassóis semeados nesta cena, permeiam todo o espetáculo, onde a cada ação dos intérpretes essas sementes ganham cada vez mais espaço e presença cênica. Para o intérprete-criador deste solo, construir um caminho que depois é apagado relaciona-se muito com as atitudes do próprio pintor ao longo de sua vida, uma vez que Van Gogh teve diversos momentos prósperos, amigos, admiradores e bons empregos, mas tudo foi muito fugaz. Assim como construía relações (tanto pessoais como profissionais) ele já as destruía, abandonava as oportunidades e procurava aporte no irmão Theo.

Para além das sementes de girassóis outra característica marcante na obra de Van Gogh e que também nos serviu de estímulo para a pesquisa de movimento foi o ritmo de sua pincelada, o qual se desdobra cenicamente em movimentos de fluxo contido e expressivo, com caráter forte e dramático. 
A Cena das Corridas (figura 7) apresenta-se como a terceira cena deste espetáculo e tem como fio condutor alguns sintomas da esquizofrenia sofrida por Van Gogh: A perda do contato com a realidade e da consciência do agora, a sensação de estar sendo perseguido, o estado catatônico lque pode ser apresentado de duas formas: o corpo permanece inerte e alheio ao que acontece no entorno, ou, o corpo executa movimentos repetidos a ponto de uma catarse), a sensação que pensamentos ou coisas estão sendo colocados por alguém no seu corpo foram alguns dos sintomas investigados pelos intérpretes-criadores aproximando gestos do cotidiano a esses estados de corpo.
Figura 7. Vincent (2017) - Cena das Corridas - Sala Álvaro Moreyra, Porto Alegre-RS.
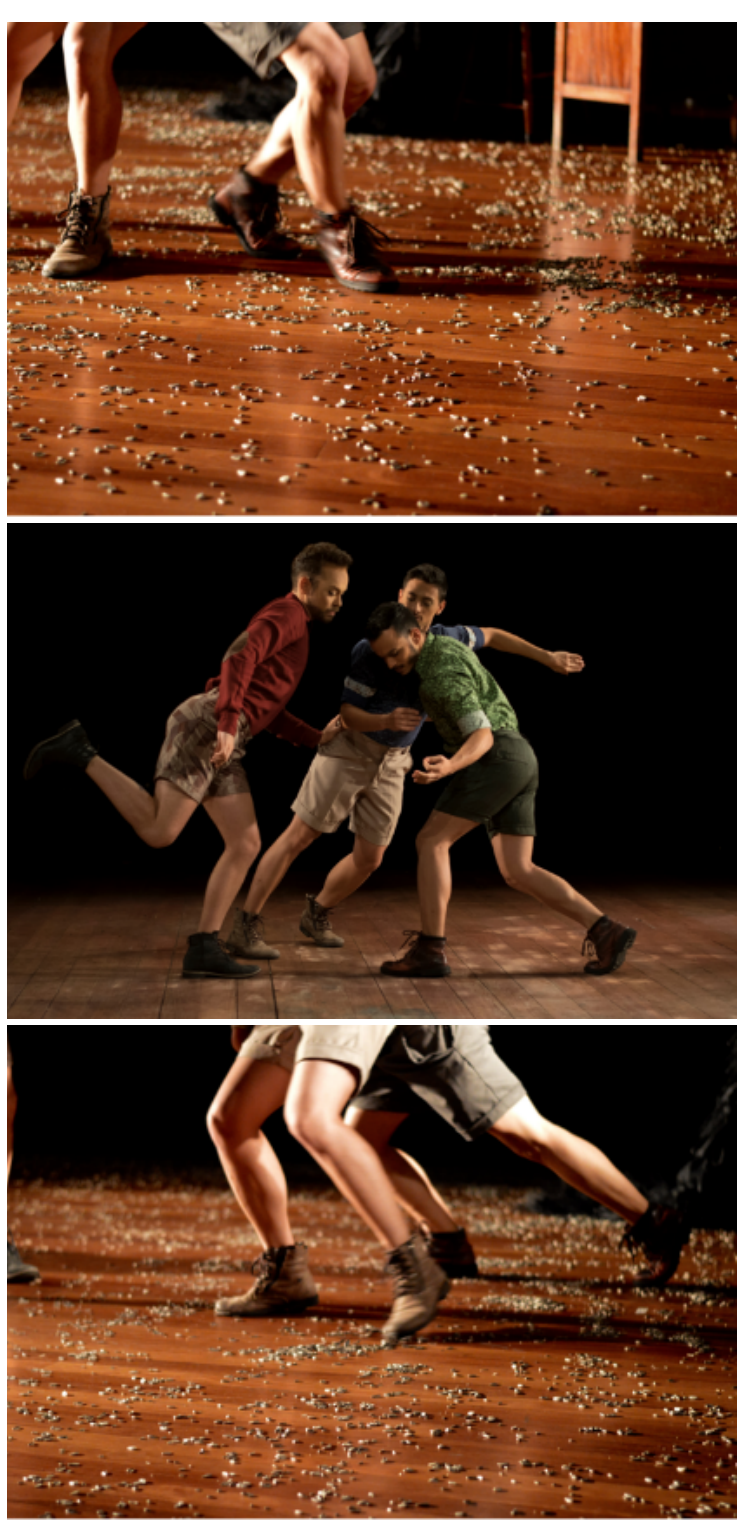

Fonte: Acervo da Cubol Cia. de Arte. Fotografia: Lu Trevisan e Luhã Valença.

A obra Campo de Trigo com Corvos (1890) nos serve nesta cena para situar os intérpretes no espaço-tempo do trágico acontecimento: o instante imediatamente anterior ao suicídio de Van Gogh diante do referido campo de trigos (figura 8). 
Figura 8. Wheatfield with Crows - Vincent van Gogh (1853 - 1890), Auvers-sur-Oise, July 1890. oil on canvas, $50.5 \mathrm{~cm} \times 103 \mathrm{~cm}$.

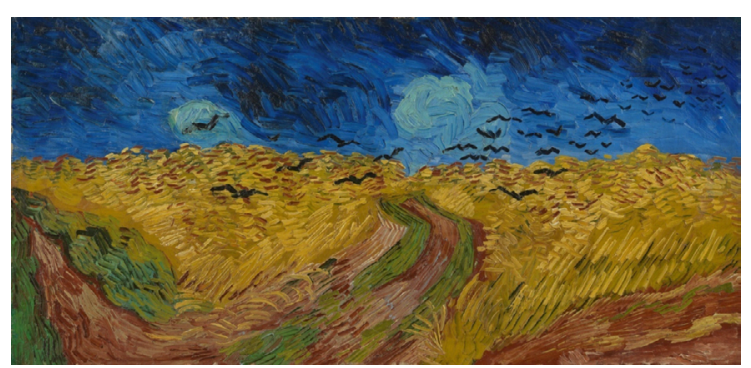

Fonte: Van Gogh Museum, Amsterdam (Vincent van Gogh Foundation).

As imagens como acontecimentos, elaboradas por Bittencourt (2012) extrapolam a noção de cópia dos objetos do mundo, indicando-as como estratégia do corpo ao se constituir corpo em veículos contaminadores dos sentidos. As imagens como acontecimentos são compreendidas nos processos de comunicação no corpo e do corpo com o mundo, num tipo específico de informação pautada pela transitoriedade. Para a autora:

\section{As imagens emergem como modos de sua própria per- cepção. Imagem no corpo é sempre uma ação que des- liza pela instabilidade dos ajustes que enfrenta para se tornar uma presentida- de. Ou seja, quando se fala em imagem, há que se levar em conta, sobretudo, o mo- vimento presente nas ações do corpo. (BITTENCOURT, 2012, p. 13).}

Segundo a autora, as imagens do mundo e as imagens do corpo se replicam e se adaptam umas às outras, motivo de sua especificidade. Entendendo "o corpo como imagem em fluxo no tempo. Todavia, o corpo não é apenas imagem em movimento. A imagem é, sobretudo, um dos modos possíveis de sua comunicação" (BITTENCOURT, 2012, p.18) e participam de sua materialidade no que diz respeito ao seu fluxo. A materialidade do corpo é da natureza da energia e do fluxo enquanto as imagens no corpo são acontecimentos em fluxo. A partir do postulado pela autora, compreendemos as imagens como acontecimentos tendo em vista seu fluxo no corpo e de sua capacidade de sinalizar o vivido, incapacitando sua cópia e possibilitando a reorganização enquanto ação, percepção e movimento. As imagens no corpo são modos de acesso ao mundo, indissociáveis.

Com isso, a composição coreográfica se dá através de um jogo que acontece no ato da cena. Como uma improvisação dirigida em dança, os intérpretes-criadores possuem algumas diretrizes, tais quais: executar dois movimentos do cotidiano repetidamente de maneira crescente até iniciar o deslocamento pelo espaço; devem se contaminar com o movimento do outro após entrarem em contato físico (realizando uma ação de troca de peso entre eles); devem manter o caráter de perseguir e ser perseguido. Essas ações se completam ao som de um metrônomo de 60 rpm que permanece em looping, fazendo com que a dinâmica da cena seja resolvida entre os intérpretes. Assim como a Cena das Cartas esta também é uma cena flutuante, pois, temos registros de sua duração em 
tempos diversos como 18 minutos, 9 minutos e 6 minutos. Frequentemente sua execução leva os bailarinos a um estado de catarse, e sua finalização se dá a partir de uma negociação conjunta no decorrer do jogo. Consideramos esta cena, portanto, um exemplo do que nos aponta Bittencourt (2013) a respeito da presentidade da imagem na ação do corpo assim como o que nos indica Setenta (2008) sobre performatividade e a presença da ação na composição de dança.

Esta cena, assim como a primeira (Cena do Brinco), sofreu um desdobramento quando realizada na Sala Álvaro Moreyra (2017 - Segunda Temporada), visto a dimensão do espaço cênico. A Sala 209 era extremamente ampla e possibilitava um maior deslocamento dos intérpretes pelo espaço, enquanto na Sala Álvaro Moreyra esta cena ganha momentos de caminhada, corridas mais curtas e algumas arrancadas que logo são interrompidas, gerando uma dinâmica coreográfica bastante diversa.

Dá-se aqui algum destaque para o espaço cênico considerando sempre a importância do espaço, o qual também chamamos de ambiente, tendo em vista o que identificam Katz e Greiner (2005) e também Berté (2014) sobre o relacionamento-afeto mútuo corpomídia-ambiente, enquanto espaço da coabitação das imagens e dos sujeitos que com ele se contaminam.

A quarta cena do espetáculo é chamada de Cena da Parede (figura 9). Esta cena surge a partir de dois pontos: o primeiro, do desejo de dois dos intérpretes-criadores em compor um duo o qual estava no planejamento da primeira temporada, porém ainda não havia sido concebido, o segundo, da ordem da ação de apagar o rastro de sementes deixado na cena número dois. A diretriz de criação era apagar a trilha de girassóis com uma movimentação sincronizada utilizando a parede do fundo da cena como suporte para criação. Traz-se aqui de novo a percepção da cena número dois, quando se fala sobre o esforço de construir e semear um caminho e depois destruí-lo. Isso foi, portanto, refletido pelos intérpretes-criadores a partir de situações vividas por eles, que envolviam a questão do empenho em algo, seguido de seu abandono, a insistência e a desistência, a perseverança e o descaso, e porque não dizer amor e rancor.

Figura 9. Vincent (2019) - $10^{\circ}$ Caxias em Movimento, Caxias do Sul-RS.

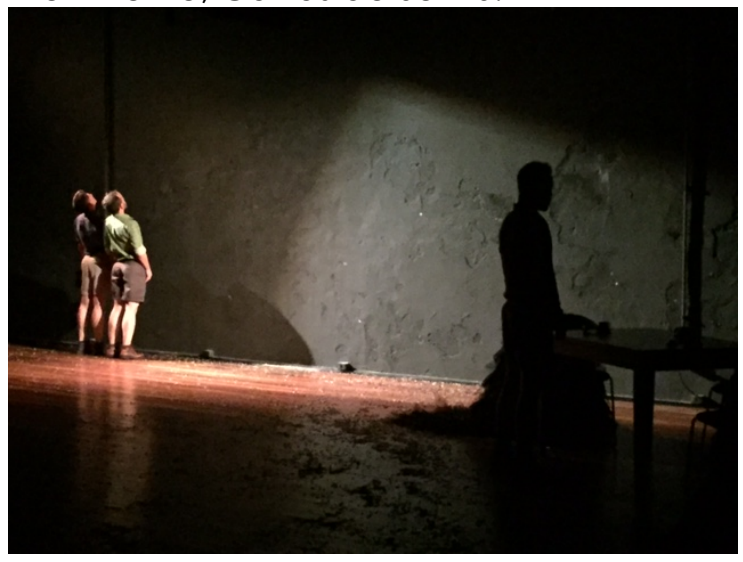

Fonte: Acervo da Cubol Cia. de Arte. Fotografia: Matheus Brusa.

Outra imagem a qual recorremos para elaboração desta cena e que remete novamente ao estado psíquico de Van Gogh está em 
pensar neste duo como imagens das vozes da mente do pintor, que se demonstram na cena como um contraponto ao terceiro bailarino que executa uma movimentação lenta referindo-se ao que essas vozes executam. Como uma espécie de eco, e porque não dizer um ruído, a composição coreográfica do terceiro bailarino não está ancorada na imagem pictórica, mas sim no vão entre imagem, estado psíquico e espaço da cena. A partir de Bittencourt (2012) podemos pensar as imagens de Vincent não pelo suporte pictórico que as materializam e que se congela em uma galeria, reificado, mas naquilo que as torna corpo, ou que em nosso caso, se corporifica em nosso fazer Dança. Tem-se com isso um trânsito entre o que se insinua a partir da imagem, mas que nela mesma enquanto obra não existe, é nisso que mora o que estamos chamando de ruído, o que se enreda e se insinua entre obra e corpo, da imagem ideia que se rompe, das imagens ideias encarnadas e que o sendo assim, não se acomodam. Deste modo, a desacomodação da imagem é matéria criativa para a composição em Dança, onde se faz coexistir tanto a própria imagem pictórica, os rastros biográficos e históricos que abrigam certo compromisso com o real e principalmente, o que é da ordem dos imaginários coletivos, pessoais e fantasiosos. É desta desacomodação da imagem ruidosa, do seu caráter não factível que se faz a matéria criativa para a composição de Vincent.
Carinhosamente atribuímos à quinta cena o nome Cena da Mesa que faz referência a obra Os Comedores de Batata (1885, figura 10). Além da pintura, um fragmento do espetáculo Can we talk about this? (2011) do grupo DV8 Physical Teatre compôs o quadro referencial para o desenvolvimento desta cena. De forma caricata e irreverente traduz através de movimentos simples e certeiros uma dança de fácil apreensão. A trilha utilizada consta do áudio extraído do documentário Os impressionistas (1998), de direção de Phil Grabsky e Ali Ray.

Figura 10. The Potato Eaters, Vincent van Gogh (1853 - 1890), Nuenen, April-May 1885 oil on canvas, $82 \mathrm{~cm} \times 114 \mathrm{~cm}$.

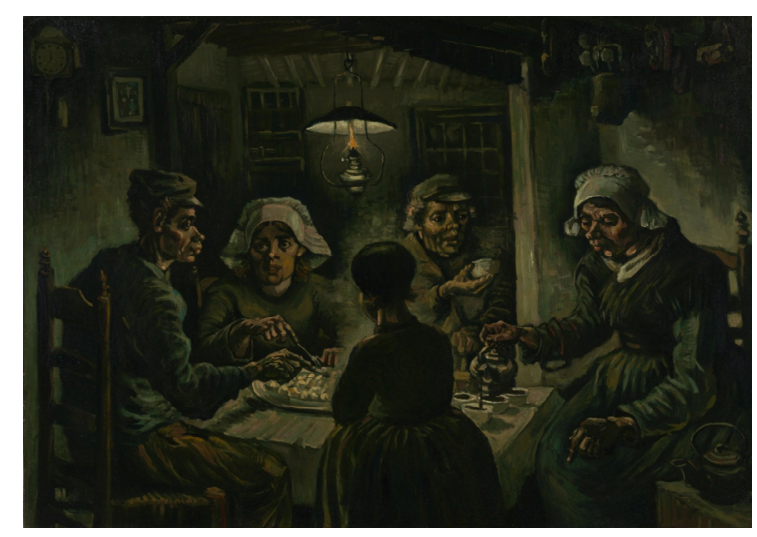

Fonte: Van Gogh Museum, Amsterdam (Vincent van Gogh Foundation).

Os elementos que compõe o cenário desta cena fazem referência ainda à obra A Cadeira com o Cachimbo (1889) como podemos ver na figura 11. A investigação dos movimentos, para além do arranjo espacial em torno da mesa partiu de uma investigação de relacionamento com a mesa atrelado ao texto do documentário. Parte das partituras coreográficas ora se re- 
10 Entre os sites que de modos diferentes comentam a vida e a obra de Van Gogh, o Van Gogh Museum, de Amsterdã é uma das principais e mais respeitadas instituições de referência, até mesmo pela participação de familiares do artista com este projeto que ganhou vida na década de 1970. lacionam com o texto, ora se opõe a ele gerando momentos de comicidade. Aborda ainda movimentos de repetição e pausas dando espaço para o texto que está sendo reproduzido, criando imagens ou reiterando àquelas sugeridas pelo texto.

Figura 11. Vincent (2017) - Cena da Mesa Sala Álvaro Moreyra, Porto Alegre-RS.
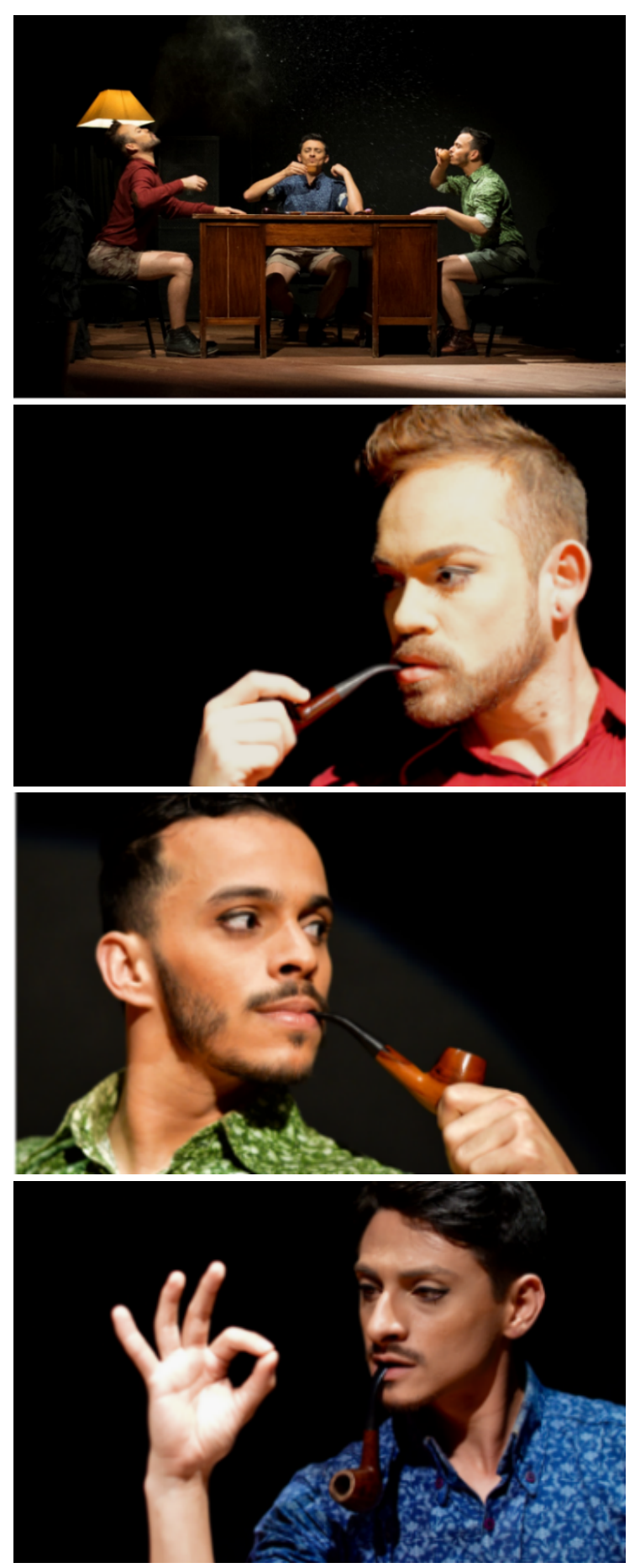

Fonte: Acervo da Cubol Cia. de Arte. Fotografia: Luhã Valença e Lu Trevisan.
Retomando o conceito corpomídia tem-se nesta cena uma brincadeira com as mensagens cruzadas entre as obras de referência, entre o texto, também gerador de imagens, e a ação coreográfica, enunciativa também por sua natureza. Cruzamento este que se mostra ruidoso e por isso, de sua capacidade de disparar múltiplas leituras. Essas leituras e afetos das imagens ruidosas têm, como nos explica Berté (2014), a capacidade de reconfigurar as informações/imagens com as quais se relaciona:

\section{Ao dançar, o corpomídia não apenas transmite uma men- sagem, ele próprio é mensa- gem que se transmite pelo movimento. O corpomídia transmite o que ele processa e reconstrói em meio às suas relações com o ambiente. Aquilo que mostra, diz, dá a ver, dança, é articulado com as informações que ele tornou corpo e que o reconfiguraram. Desse modo, compreendo que o corpo é mídia, mensagem, imagem. (BERTÉ, 2014, p. 78).}

A sexta cena do espetáculo é chamada de Cena das Cartas. Podemos dizer que se Van Gogh teve um amigo verdadeiro, essa pessoa foi o Carteiro Rolin. Na verdade, segundo informações fornecidas no site $^{10}$ consultado que trata do pintor, Rolin não era um carteiro, mas sim um funcionário dos Correios que trabalhava no setor de Triagem. Van Gogh pintou diversos retratos de Rolin (figura 12) em forma de agradecimento pela sua amizade e principalmente por ser ele quem the entregava as cartas de seu irmão Theo. 
Figura 12. Portrait of the postman Joseph Roulin, Vincent van Gogh (1853 - 1890), 1888.

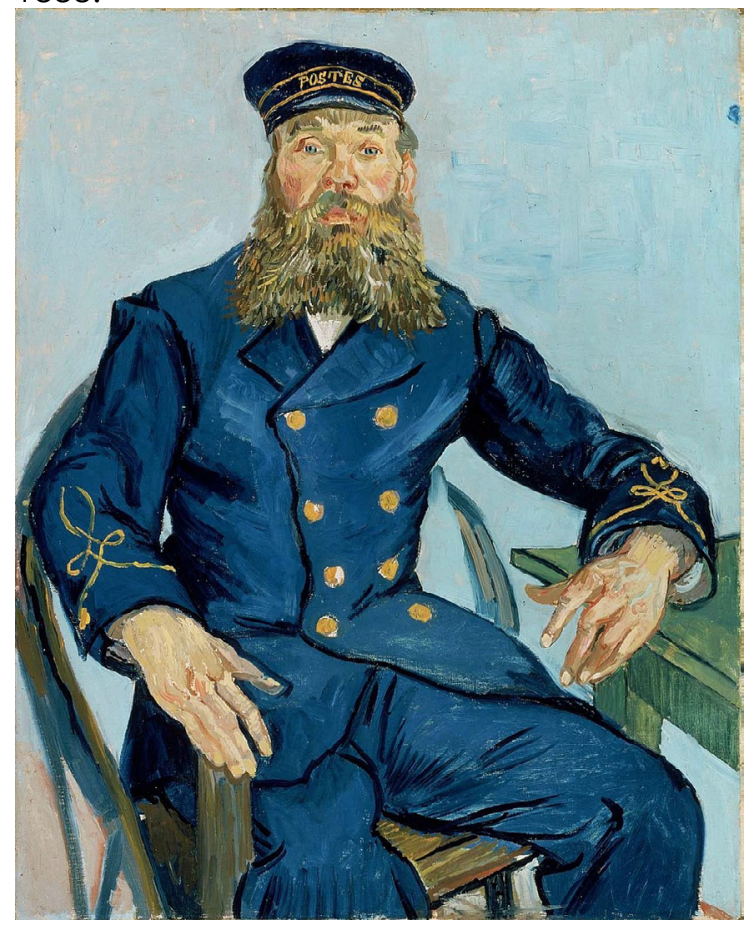

Fonte: Museum of Fine Arts, Boston. https:// joyofmuseums.com/museums/unitedstates-of-america/philadelphia-museums/ barnes-foundation/portrait-of-thepostman-joseph-roulin/.

No espetáculo, dois intérpretes-criadores se dirigem à plateia e entregam envelopes aos espectadores, cujo conteúdo consta de um pequeno livro-arte feito a mão e criado exclusivamente para o referido espetáculo. Cada envelope é entregue seguido de uma frase que ora faz alusão às cartas que Van Gogh escrevia ao irmão, ora se relaciona com alguma característica física do espectador que vai recebê-lo. Esta é, portanto, uma cena aberta, sem tempo delimitado para que seja concluída, caracterizando-se como uma cena flutuante, pois depende também do número de pessoas na plateia. Atenta-se aqui, para contrapor o argumento utilizado anteriormente sobre a multiplici- dade de leitura das imagens geradas, o aspecto intencional de trazer o público, também corpomídia da ação performativa, para compor a ação e desta forma selecionar algo das imagens com as quais se relacionar. Como nos explica Berté: "Ao perceber-se desafiado por informações, imagens, eventos e fenômenos do ambiente, através de relações que estabelece e das quais faz parte, o corpo questiona o que já sabe, interpela a novidade, seleciona, agrega, processa, transforma". (BERTÉ, 2014, p. 77) .

A penúltima cena de Vincent, Cena dos Corvos (figura 13), acontece de maneira concomitante e complementar. Visualmente ela se apresenta bipartida no espaço e traz duas referências: a direita ao fundo vislumbramos duas figuras que nos remetem aos corvos da obra Campo de Trigo com Corvos (1890), e a esquerda à frente, o que entendemos como o tormento imediatamente anterior ao suicídio no tempo em que o pintor permanece em agonia até a chegada de seu irmão Theo na cidade de Auvers. Alguns biógrafos e historiadores apontam que os corvos que aparecem na obra O Campo de Trigo com Corvos já seria um mau presságio anunciado por Van Gogh de maneira subliminar. Essa ideia do mau presságio é apresentada nessa cena de maneira multifacetada: é ao mesmo tempo uma criatura gigante e esmagadora, é fumaça, nuvem, é algo que anda sozinho, que assombra, amedronta, que é real e imaginário, visível e invisível, alguma coisa que avança e recua, que se aproxima sem ser notado. 
Figura 13. Vincent (2017) - Cena dos Corvos - Sala Álvaro Moreyra, Porto Alegre-RS.
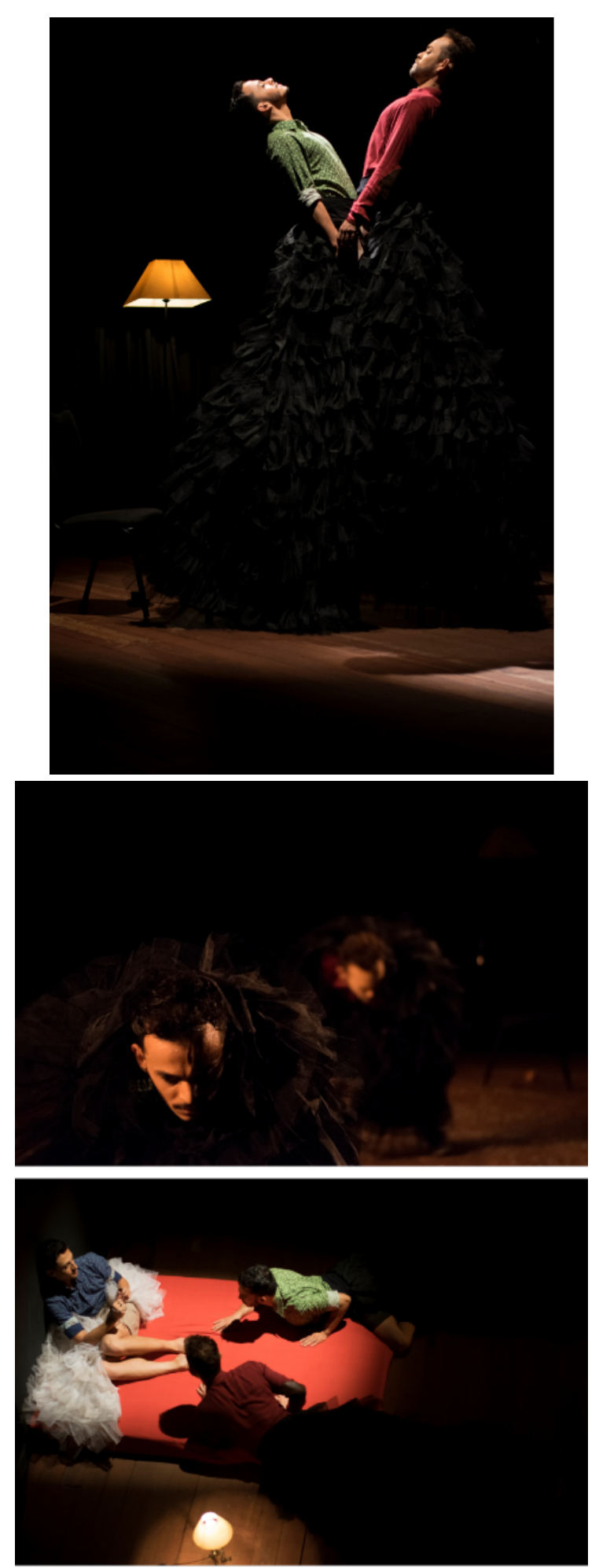
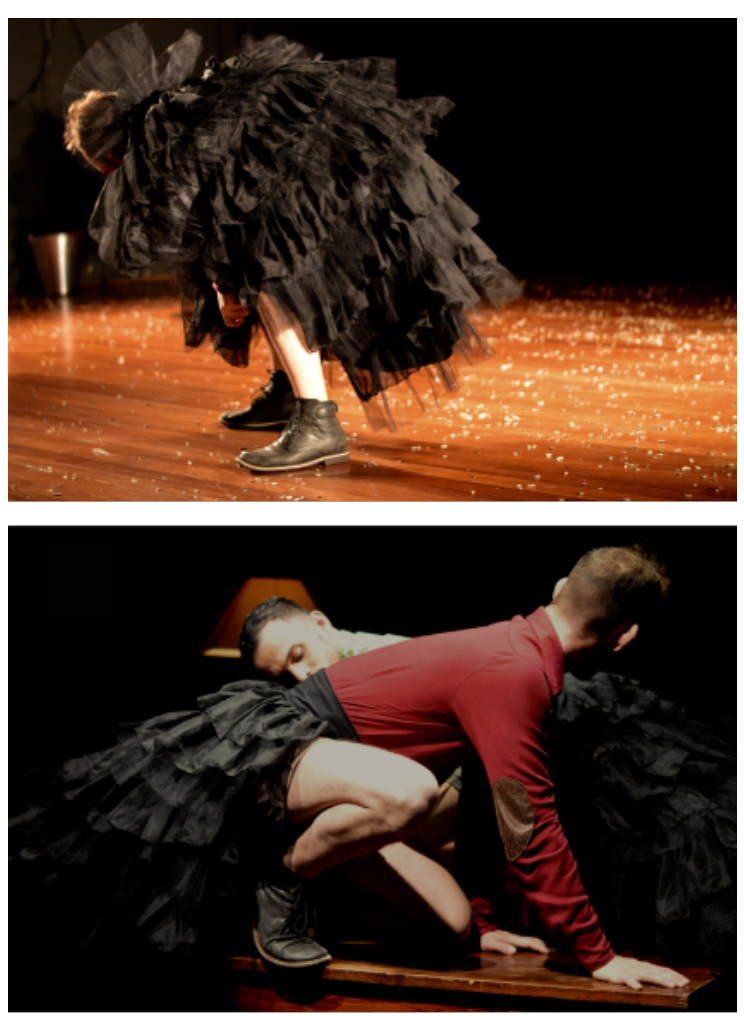

Fonte: Acervo da Cubol Cia. de Arte. Fotografia: Luhã Valença e Lu Trevisan.

A composição cênica a partir das obras citadas cria uma imagem de seres amorfos, disformes trazendo um caráter sombrio que toma o espaço. Através de um panorama de abordagens teórico-conceituais da imagem, passamos ao estudo de Berté (2018), buscando pela explanação do corpo que cultiva imagens, forma imagens a partir de suas interações com o mundo e dá a ver imagens em suas criações. $\bigcirc$ figurino, negro e volumoso, é o elemento chave na composição desta cena uma vez que manipulado pelos bailarinos desencadeia uma visualidade, dispara imagens de aspecto denso e umbroso.

Tais elementos, visíveis na imagem 12, evocam o que Berté (2014) parafraseando Damásio (2009) apresenta enquanto "símbolo percebido ou imaginado, os próprios 
sentimentos, são imagens, ou seja, imagens sômato-sensitivas que sinalizam aspectos dos estados de corpo". (BERTÉ, 2014, p. 75).

A última cena do espetáculo é chamada de Procissão (figura 14). De todos os entrecruzamentos promovidos entre a obra e os acontecimentos da vida de Van Gogh com as memórias e vivências dos intérpretes-criadores, esta cena é a mais carregada de significados e de particularidades onde fez-se 0 uso de imagens do imaginário coletivo referentes à religiosidade, fé e espiritualidade de Van Gogh.

Figura 14. Vincent (2017) - Cena da Procissão - Sala Álvaro Moreyra, Porto Alegre-RS.
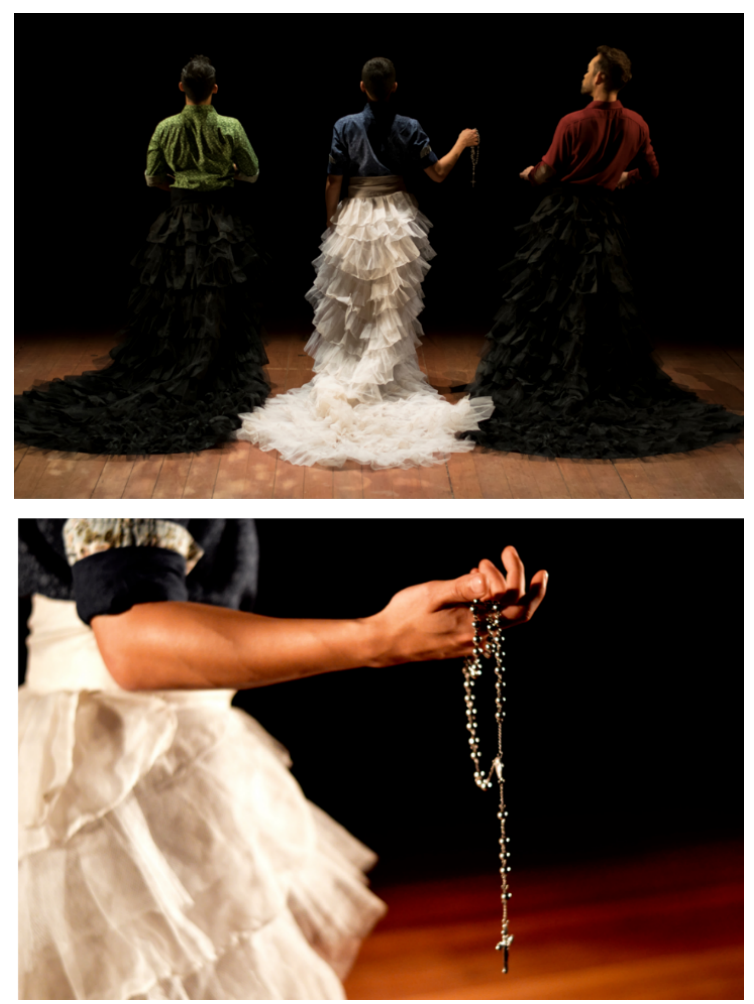

Fonte: Acervo da Cubol Cia. de Arte. Fotografia: Luhã Valença e Lu Trevisan.

Foi na oscilação da fé do artista, no seu breve trabalho enquanto pregador dos ensinamentos mis- sionários e na sua obra Pietá (1889) (figura 15) que encontramos aporte para a criação desta cena. Os bailarinos deslocam-se em fila, numa espécie de procissão, onde cada um entoa uma oração diferente, relacionada às suas crenças. Assim, temos a entoação de uma Salve Rainha, de um Pai Nosso Cardecista e de uma Reza de Yemanjá, em Yorubá. A entonação crescente conduz ao final do espetáculo que apresenta uma última imagem, um crucifixo portado pelo bailarino cai ao chão encerrando abruptamente a voz de todos, seguido de um blackout. Aqui destaca-se a coabitação das imagens geradas pelas rezas entoadas e pela materialização de diferentes abordagens de fé enquanto ruído evocativo da memória. Desdobram-se imagens que mais uma vez não buscam ser fiéis àquilo vivido por Van Gogh, tampouco o que se retrata em suas obras, mas do ruído que encerra - espetáculo, na imagem-som da entoação, na queda do crucifixo de metal, na cauda da noiva, na procissão, no cortejo, na ladainha, na noite estrelada e no silêncio que finaliza a ação (momento máximo do breu do silêncio, onde o ruído ecoa). 
Figura 15. Pietá, Vincent van Gogh (1853 1890), 1889.

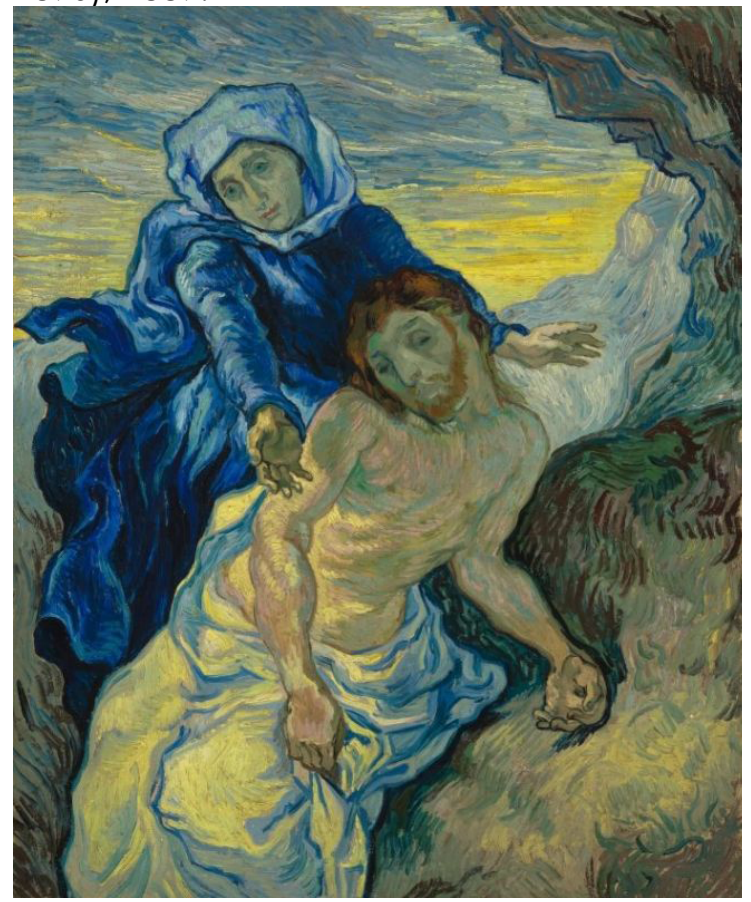

Fonte: Van Gogh Museum, Amsterdam (Vincent van Gogh Foundation). https:// www.vangoghmuseum.nl/en/collection/ s0168V1962.

\section{Considerações}

A elaboração deste estudo buscou demonstrar os caminhos percorridos na criação do espetáculo Vincent e como este processo esteve cercado de imagens que se confrontaram e alimentaram as vivências mais profundas dos intérpretes-criadores. Os conceitos abordados nesta pesquisa não encerram em si um modo ou modelo teórico sobre Dança, antes, elaboram caminhos de compreensão que fortalecem e propulsionam essa prática. Além disso, aproximar dança e cultura visual, nos parece o entremeio das dinâmicas corpomídia (KATZ; GREINER, 2005), de como elaboramos a memória individual e coletiva de nossa relação com as imagens de Van Gogh.

Deste modo, percebe-se que esta investigação se elaborou de imagens a todo instante: obras de arte, representações de obras de arte, artefatos do artista, romances, cartas, esquizofrenias, ficções e ruído. Tudo aquilo que não era de fato uma imagem tornava-se uma na medida em que transitava pelos corpos dos intérpretes-criadores. Concordamos, então, com Katz; Greiner (2005) quando apontam a mutualidade de afetos entre corpo e meio, sobre como ambos se atualizam/reiteram/questionam/modificam a todo tempo, incessantemente.

Entendemos este meio para além de fronteiras geográficas e especiais, onde de maneira comple$x a$, o meio se dá entre o contexto social/político/econômico/cultural/ 
afetivo do artista que é referência para a criação, os corpos dispostos a revisitá-lo e principalmente nos corposmídia a relacionarem-se ruidosos. Estamos falando da disparidade da qual os corpos dos intérpretes-criadores percebiam e reconstruíam as informações sobre Van Gogh. Ainda sobre as imagens ou artefatos de arte que nos acometeram ao estado de criação em dança, estamos abraçados à proposição de Berté (2015) quando, ao elaborar o termo sobre sua dança "Contempop", expõe a triádica faceta quanto ao uso e compreensão das imagens em sua poética: "imagem-artefato, imagem-ideia e imagem-ação".

Dos conceitos e modos operantes, da criação do espetáculo Vincent e de tudo que moveu os corpos dispostos a dar carne a 'um outro' Van Gogh, podemos destacar o modo de dança, ou ainda o estado de dança que nutre esta criação e acolhe o ruído como algo da quebra das linearidades narrativas: A dança performativa, delineada por Setenta (2008). A autora aponta o corpo como enunciativo de si mesmo, sendo aplicado em nosso caso na proposição de transitar pelas obras de Van Gogh sem necessariamente constituir ilustrações das obras de referência, de modos distintos de expressar essas relações. Ainda que empenhados do mesmo propósito (a criação) cada corpomídia é e está entre pontos de vista particulares, logo, as linguagens de cada corpo que dança nesta proposição, tende a se modificar, tratando o corpo como "produtor de questões" e não apenas como "receptáculo reprodutor de passos ordenados". (SETENTA, 2008, p. 20).

Ainda que exista um referencial externo (pesquisa sobre Van Gogh) e que esse referencial para Setenta (2008) seja deflagrador do modo constativo de enunciação, a imersão neste processo de criação é levado à cena em um continuum, sempre em relação ao tempo presente. Deste modo o ver-sentir-pensar apresentado anteriormente torna-se (re)ver-(re)sentir-(re)pensar a vida e obra de Van Gogh. Entendemos que essa relação possibilita/instrumentaliza a construção do repertório de movimentos/gesto/ação que se dá no tempo em que se dança. Desse modo não se conta uma história linearmente (sobre Van Gogh), mas atenta-se para a ação-dança impregnada (com Van Gogh) de outras ruidosas imagens. Nesta linha de pensamento, entendemos a importância das pesquisas especializadas sobre a vida e obra de um dos maiores gênios da pintura e destacamos alguns dos pontos que se apresentaram a partir dessas pesquisas para subvertê-los em atos de transcriação: o suicídio de Van Gogh ainda é discutido e problematizado atualmente, suposição que adotamos como investigação criativa para Vincent; os sintomas da suposta esquizofrenia de Van Gogh, tomada como pauta investigativa para qualidades de movimentos e mencionadas no texto, não possui relação de verdade com o vivido por Van Gogh, tendo em vista a falta de indícios que confirmem este tipo de diagnóstico (NAIFEH; SMITH, 2012; MORRANT, 1993; HEM- 
PHILL, 1961); quando nos utilizamos da fé de Van Gogh, nos referimos a forte influência da "espiritualidade" (MELO, 2020) em seu trabalho e em sua trajetória, refletida na cena Procissão, sem necessariamente apresentar correlações entre sua fase religiosa missionária e protestante.

É nesse sentido que destacamos o aspecto do ruído da imagem, trabalhando a composição em dança a partir das frestas que antecedem a própria imagem, não apenas o seu estado/ação enquanto desdobramento. As imagens da obra de Van Gogh para a criação em dança analisadas aqui são então percebidas como ruído da ação, portanto do corpo e das características que o compõe. A imagem e o próprio corpo geram ruídos e atritos que disparam possibilidades não obvias para o acesso de novas perspectivas, sobremaneira no caso da reconhecida obra do pintor holandês Vincent Van Gogh. Com isso o que apresentamos enquanto imagem ruído não busca ser um conceito operatório nesta análise, mas esboça-se enquanto noção pertinente ao estudo.

As imagens da arte tendem a desdobrarem-se em fragmentos e gatilhos, testemunhos e ruídos do corpo e da ação do artista para serem outra coisa de dança, de novos enredos e ficções. O ruído do entre imagens-mundos colabora assim com a pesquisa de movimentos em dança pois pensamos que é do ruído das imagens, do breu de sua infinitude que o movimento se multiplica, do que as imagens são e da potência do que não são, do que deixaram de ser. O que se desdobra no corpo em dança se percebe quando apostamos em tudo que a imagem ruído manifesta, na presunção de morte de seu ato, seu devir, outras imagens. 


\section{Referências}

BERNARD, Michel. De la création chorégraphique. Centre national de la danse, 2001.

BERTÉ, Odailso. VOGUE: dança a partir de relações corpo-imagem. Dança, Salvador, v. 3, n. 2, p. 69-80, jul./dez. 2014.

BERTÉ, Odailso. Dança contempop: corpos, afetos e imagens (mo)vendo-se. Santa Maria: Editora UFSM, 2015.

BERTÉ, Odailso. O movimento criativo e pedagógico de Frida Kahlo. Fundação de Apoio a Tecnologia e Ciência. Santa Maria: Editora UFSM, 2018.

BITTENCOURT, Adriana. Imagens como acontecimentos: dispositivos do corpo, dispositivos da dança. Salvador: EDUFBA, 2012.

CALDEIRA, Solange. A construção poética de Pina Bausch. POIÉsIS, v. 11, n. 16, p. 118-131, 2010.

DAMÁSIO. António. O mistério da consciência: do corpo e das emoções ao conhecimento em si. São Paulo: Companhia das Letras, 2009.

DAMÁSIO, António R. E o cérebro criou o homem. Tradução de Laura Teixeira Motta. São Paulo: Companhia das Letras, 2011.

HEMPHILL, R. E. The lllness of Vincent van Gogh. Proceedings of the Royal Society of Medicine, v. 54, n. 12, p. 1083-1088, 1961.

JANSON, Horst Woldemar. História geral da arte: o mundo moderno. Martins Fontes, 2001.

KATZ, Helena; GREINER, Christine. Por uma teoria do corpomídia ou a questão epistemológica do corpo. Colección Teoría de las Artes Escénicas-Archivo Virtual: Disponível em: http://archivoartea.uclm.es/textos/por-uma-teoria-do-corpomidia-ou-a-questao-epistemologica-do-corpo/. 2005. Acesso em: 29 jan. 2021.

KOSSOY, Boris. Realidades e ficções na trama fotográfica. $3^{a}$ ed. Cotia: Ateliê Editorial, 2002.

LOBO, Lenora; NAVAS, Cássia. Teatro do movimento: um método para o intérprete criador. Brasília: Secretaria de Estado da Cultura do DF: LGE, 2007. 
MARTINS, Raimundo. A cultura visual e a construção social da arte, da imagem e das práticas do ver. In: OLIVEIRA, Marilda Oliveira de. (Org.). Arte, educação e cultura. Santa Maria: Editora da UFSM, 2007.

MELO, Diana Karine Oliveira de. Arte e logoterapia: a espiritualidade na vida e obra de van gogh. Trabalho de Conclusão de Curso (Psicologia). Universidade Federal da Paraíba, 2020. Disponível em: https://repositorio.ufpb.br/ jspui/handle/123456789/18118. Acesso em: 29 jan. 2021.

MORRANT, J.C. The wing of madness: the illness of Vincent van Gogh. The Canadian Journal of Psychiatry, v. 38, n. 7, p. 480-484, 1993.

NAIFEH, Steven; SMITH, Gregory White. Van Gogh: a vida. Tradução de Denise Bottmann. São Paulo: Companhia das Letras, 2012.

PESAVENTO, Sandra Jatahy. Narrativas, imagens e práticas sociais: percursos em história cultural. Porto Alegre: Asterisco, 2008.

SETENTA, JUssara Sobreira. O fazer-dizer do corpo: dança e performatividade. EDUFBA, 2008.

TOURINHO, Irene; MARTINS, Raimundo. Reflexividade e pesquisa empírica nos infiltráveis caminhos da cultura visual. In: MARTINS, Raimundo; TOURI$\mathrm{NHO}$, Irene. (Orgs.). Processos e Práticas de Pesquisa em Cultura Visual e Educação. Santa Maria: Editora da UFSM, 2013.

VAN GOGH, Vincent. Cartas a Théo. Tradução de Pierre Ruprecht. Porto Alegre: L\&PM, 2016.

Recebido em: 23/jul/2020

Aceito em: 8/dez/2020 